\title{
DÜBLIN
}

Technological University Dublin

ARROW@TU Dublin

2009-01-01

\section{Emitter-wrap-through Photovoltaic Dipole Antenna with Solar Concentrator}

\author{
Maria Roo Ons \\ Technological University Dublin
}

S. Shynu

Technological University Dublin

Max Ammann

Technological University Dublin, max.ammann@tudublin.ie

See next page for additional authors

Follow this and additional works at: https://arrow.tudublin.ie/engscheceart

Part of the Electrical and Computer Engineering Commons

\section{Recommended Citation \\ Ons, R., et al. (2009) Emitter-wrap-through photovoltaic dipole antenna with solar concentrator. Electronics Letters,February 26 2009, Vol.45, pp.241-242. doi:10.1049/el:20093617}

This Article is brought to you for free and open access by the School of Electrical and Electronic Engineering at ARROW@TU Dublin. It has been accepted for inclusion in Articles by an authorized administrator of ARROW@TU Dublin. For more information, please contact arrow.admin@tudublin.ie, aisling.coyne@tudublin.ie, gerard.connolly@tudublin.ie.

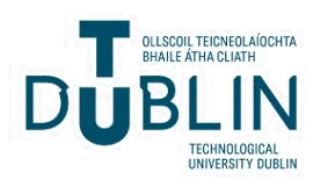


Authors

Maria Roo Ons, S. Shynu, Max Ammann, Sarah McCormack, and Brian Norton

This article is available at ARROW@TU Dublin: https://arrow.tudublin.ie/engscheceart/28 


\section{Emitter-wrap-through photovoltaic dipole antenna with solar concentrator}

M.J. Roo Ons, S.V. Shynu, M.J. Ammann, S.J. McCormack and B. Norton

A novel photovoltaic dipole antenna employing a solar concentrator as a reflector is proposed. Four identical emitter-wrap-through rear contact solar cells connected in series as a folded dipole are simultaneously used for power generation and as the antenna radiating element, which is located in the focal line of a parabolic solar concentrator The parabolic structure acts as a solar concentrator for the photovoltaic cells as well as a reflector for the folded dipole antenna. Full-wave electromagnetic simulation with supportive experimental work validates this design. The measured fractional impedance bandwidth and gain were $21 \%$ and $11.1 \mathrm{dBi}$, respectively. The antenna/solar arrangement provide a power output of $73.7 \mathrm{~mW}$ for an irradiance of $1000 \mathrm{Wm}^{-2}$.

Introduction: The combination of solar cells and radiating elements into a single device is very attractive in communication systems in order to save space and to reduce installation costs by increasing the potential of emerging compact technologies. It has been shown in space satellite applications that photovoltaic (PV) cells can be located close to microstrip antennas, avoiding the region where the effective electric fringing field exists [1]. The development of thin amorphous silicon technology on flexible polymer substrates enables solar cells to fit into complex antenna geometries, but with lower photovoltaic cell efficiency [2]. In recent years increased attention has been focused on the use of polycrystalline silicon solar cells. They have been used as radiating patches owing to their homogenous metallic rear contact, and also as a ground plane for microstrip antennas [3, 4].

A new approach in solar antenna design is proposed using a parabolic solar concentrator to increase the illuminated flux on the PV surface, thus reducing the amount of PV material required, and simultaneously acting as an antenna reflector. The electrically conductive emitterwrap-through (EWT) solar cells are used as antenna elements, where the solar array is connected in series in the form of a folded dipole. A compact decoupling circuit at the dipole feed is used to separate the $\mathrm{RF}$ and DC currents.

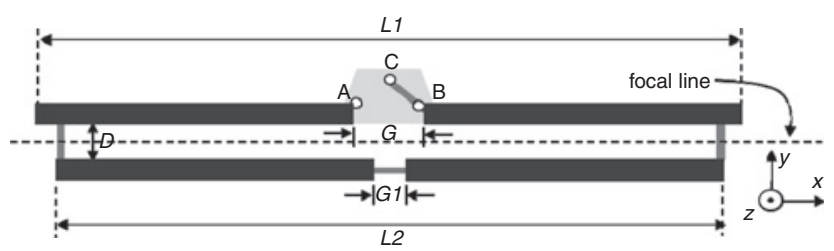

Fig. 1 Solar folded dipole with dimensions $L 1=85 \mathrm{~mm}, L 2=82 \mathrm{~mm}, D=$ $4 \mathrm{~mm}, \mathrm{G}=5 \mathrm{~mm}, \mathrm{Gl}=2 \mathrm{~mm}$

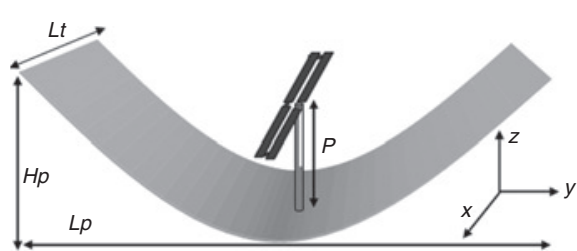

a

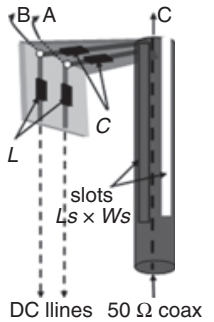

$b$
Fig. 2 Solar folded dipole antenna with parabolic reflector

$a$ Perspective view of proposed antenna with dimensions $L t=205 \mathrm{~mm}, \mathrm{Hp}=$ $75 \mathrm{~mm}, L t=245 \mathrm{~mm}$ for parabolic reflector with focal line at $P=55 \mathrm{~mm}$ $b$ RF-DC decoupling network with dimensions $L s=45 \mathrm{~mm}, W s=1.9 \mathrm{~mm}$ for slot illustrating balun on $50 \Omega$ line

Use of EWT rear contact solar cell: Conventional crystalline and amorphous silicon solar cells used so far in solar antenna approaches have contact metallisation on both front and rear surfaces to extract current [5]. In the EWT, the front surface of the cells used is devoid of any metallisation so that the complete cell surface is available for light absorption [6]. Even though the emitter is located near the front, both negative and positive polarity contacts are placed on the rear surface with the negative contact connected to the front through emitter wrapped holes. Consequently, for this type of cell there is no fully covered metallisation on any side, just an interdigitated structure alternating positive and negative polarity metal fingers. The RF behaviour was investigated at microwave frequencies and it was found to behave very closely to that of a conducting strip.

Antenna design: The proposed folded dipole consists of four identical $40 \times 3 \mathrm{~mm}$ rear contact solar cells interconnected in series, as shown in Fig. 1. The dimensions of the folded dipole arms are $L_{1}=85 \mathrm{~mm}$ and $L_{2}=82 \mathrm{~mm}$, with a feed gap of $G=5 \mathrm{~mm}$. The spacing between the arms is $D=4 \mathrm{~mm}$. The $300 \Omega$ input impedance of the folded dipole is reduced to $200 \Omega$ by the introduction of the parabolic solar concentrator (see Fig. 2a). A split-coaxial balun is implemented by introducing two identical slots of dimensions $L s=45 \mathrm{~mm}$ and $W_{S}=1.5 \mathrm{~mm}$ on opposite sides of the outer conductor of the semi-rigid Flexiform 402 NM $50 \Omega$ coaxial line, as shown in Fig. $2 b$. A 4:1 impedance transformation is achieved with this balun by adjusting the slot length [7].

Since the solar cells in the presented structure are working simultaneously as power sources and microwave radiating elements, a DC/ RF decoupling circuit is necessary, which is integrated into the feed gap of the folded dipole solar antenna. A standard arrangement of chip capacitors and inductors $(C=100 \mathrm{pF}, L=68 \mathrm{nH})$ is used to isolate the DC and RF, as shown in Fig. $2 b$. The folded solar dipole antenna is then positioned along the focal line of the parabolic concentrator, with the active side of the cells facing the reflector. The DC connection and feedline pass through a $9 \mathrm{~mm}$ radius hole to the back of the reflector.

The design was optimised using a full-wave electromagnetic simulator, CST Microwave Studio. For a parabolic trace following the curve $z=0.005 y^{2}$, the vertical distance between the antenna and reflector for a $200 \Omega$ input impedance at the dipole was found to be $P=$ $55 \mathrm{~mm}$. The required parabolic reflector dimensions are $L t>85 \mathrm{~mm}$ and $H p>55 \mathrm{~mm}$ for maximum light concentration, but the actual dimensions chosen were $L t=205 \mathrm{~mm}$ and $H p=75 \mathrm{~mm}$ to ensure a minimum gain of $10 \mathrm{dBi}$ over the entire band. $3 \mathrm{M}$ Vikuiti $^{\mathrm{TM}}$ Enhanced Specular Reflector Film was used as the conducting reflector surface. The advantage of selecting a folded dipole over an ordinary dipole is the fact that the series connection of solar cells provides additive DC voltages, as well as its broader bandwidth and convenient matching.

Results and discussion: The simulated and measured $S_{11}$ of the proposed antenna is shown in Fig. 3 with good agreement. The measured return loss was found to be greater than $10 \mathrm{~dB}$ in the frequency range $1.35-1.68 \mathrm{GHz}$, which corresponds to a fractional impedance bandwidth of $21 \%$. The measured and simulated $\mathrm{E}$ - and $\mathrm{H}$ - plane normalised radiation patterns for centre frequency are shown in Fig. 4. The measured gain at the centre frequency was found to be $11.1 \mathrm{dBi}$ with little variation across the band. The front-to-back ratios for the E- and $\mathrm{H}$ - planes were better than 27 and $30 \mathrm{~dB}$ respectively. The measured cross-polar rejection is better than $20 \mathrm{~dB}$ for both planes.

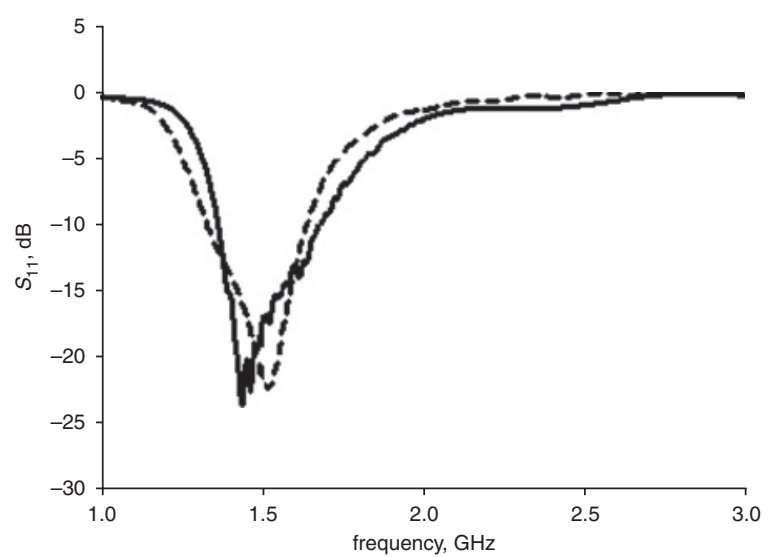

Fig. 3 Simulated and measured $S_{11}$ plots for proposed EWT dipole antenna measurement - - - - simulation

\section{ELECTRONICS LETTERS 26th February 2009 Vol. 45 No. 5}



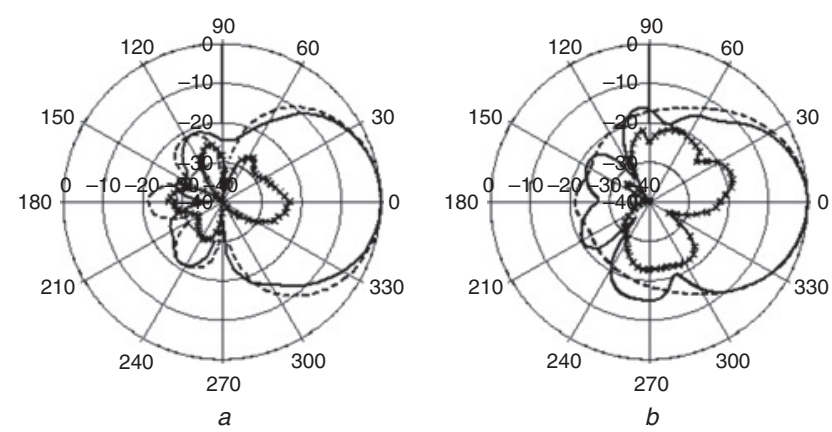

Fig. 4 Measured radiation patterns at $1.49 \mathrm{GHz}$

$a$ E-plane $(z x)$

co-polar measuremen

$x_{-}$cross-polar measurement

- - - - - co-polar simulation

$b$ H-plane (zy)

co-polar measurement

${ }_{-}{ }_{-}$cross-polar measurement

- . - - co-polar simulation

Single junction silicon solar cells provide approximately $0.5-0.6 \mathrm{~V}$, independently of the cell size. The dipole comprising four cells in series realised a voltage of $2.22 \mathrm{~V}$. The behaviour of the solar dipole as a power source was investigated by illumination with a Griven INSE 1200 MSR metal halide lamp continuous solar simulator. The solar cells face towards the parabolic reflector and a $10 \%$ increase in current was achieved where the dipole was placed at the concentrator focal line, in comparison to the standalone dipole directly facing the light. The four cell solar dipole supplies $73.7 \mathrm{~mW}(I=33.2 \mathrm{~mA}, V=$ $2.22 \mathrm{~V}$ ) at an irradiance of $1000 \mathrm{Wm}^{-2}$ for the reflector with $3 \mathrm{M}$ Vikuiti ESR film.

Conclusions: A novel folded dipole comprising EWT rear contact solar cells with a parabolic solar concentrator reflector is proposed. The full integration of solar cells and antenna in one device where the PV cells act as the RF radiating element is demonstrated. A maximum antenna gain of $11.1 \mathrm{dBi}$ is achieved over a $21 \%$ bandwidth. The parabolic reflector works simultaneously as an antenna reflector and as a solar concentrator increasing the current output by $10 \%$.

Acknowledgment: This work was supported by Science Foundation Ireland (SFI) and the research support unit of DIT.

(C) The Institution of Engineering and Technology 2009

17 December 2008

Electronics Letters online no: 20093617

doi: 10.1049/el:20093617

M.J. Roo Ons, S.V. Shynu and M.J. Ammann (School of Electronic and Communications Engineering, Dublin Institute of Technology, Kevin Street, Dublin 8, Ireland)

E-mail: mariajose.rooons@student.dit.ie

S.J. McCormack and B. Norton (Dublin Energy Lab, Focas Institute, Camden Row, Dublin 8, Ireland)

\section{References}

1 Tanaka, M., Suzuki, Y., Araki, K., and Suzuki, R.: 'Microstrip antennas with solar cells for microsatellites', Electron. Lett., 1996, 31, pp. $263-266$

2 Vaccaro, S., Mosig, J.R., and De Maagt, P.: 'Two advanced solar antenna SOLANT designs for satellite and terrestrial communications', IEEE Trans. Antennas Propag., 2000, AP-51, (8), pp. 2028-2034

3 Bendel, C., Henze, N., Weitz, M., Hofmann, P., and Kirchhof, J.: 'Investigations on planar antennas with photovoltaic solar cells for mobile communications'. IEEE Int. Symp. on Personal, Indoor and Mobile Radio Communication (PIMRC), 2004, Vol. 1, pp. 622-626

4 Shynu, S.V., Roo Ons, M.J., Ammann, M.J., McCormack, S.J., and Norton, B.: 'Inset-fed microstrip patch antenna with integrated polycrystalline photovoltaic solar cell'. Second European Conf. on Antennas and Propagation (EuCAP), Edinburgh, UK, November 2007

5 Lasnier, F., and Gan Ang, T.: 'Photovoltaic engineering handbook' (CRC Press, 1990)

6 Van Kerschaver, G., and Beaucarne, G.: 'Back-contact solar cells: a review', Prog. Photovolt.: Res. Appl., 2006, 14, pp. 107-123

7 Makarov, R., and Ludwig, R.: 'Analytical model of the split-coaxial balun and its application to a linearly polarized dipole or a CP turnstile', IEEE Trans. Antennas Propag., 2007, AP-55, (7), pp. $1909-1918$ 